\title{
Optimising seedling management: Pouteria sapota, Diospyros digyna, and Cedrela odorata in a Mexican rainforest
}

\author{
Martin Ricker $^{\mathrm{a}, *}$, Christina Siebe ${ }^{\mathrm{b}}$, Silvia Sánchez B. ${ }^{\mathrm{b}}$, Kumiko Shimada ${ }^{\mathrm{b}}$, \\ Bruce C. Larson ${ }^{\mathrm{c}}$, Miguel Martínez-Ramos ${ }^{\mathrm{d}}$, Florencia Montagnini ${ }^{\mathrm{e}}$ \\ a Jardín Botánico del Instituto de Biología, Universidad Nacional Autónoma de México, Apartado postal 70-614, \\ Delegación Coyoacán, México D.F. 04510, Mexico \\ b Instituto de Geología, Departamento de Edafología, Universidad Nacional Autónoma de México, \\ Apartado postal 70-296, Delegación Coyoacán, México D.F. 04510, Mexico \\ ${ }^{c}$ Yale University, School of Forestry and Environmental Studies, 360 Prospect Street, New Haven, CT 06511, USA \\ ${ }^{\mathrm{d}}$ Instituto de Ecología, Departamento de Ecología de los Recursos Naturales, Universidad Nacional Autónoma de México, \\ Apartado postal 27-3, Xangari, Morelia, Michoacán 58089, Mexico \\ ${ }^{\mathrm{e}}$ Tropical Agriculture Research and Training Center (CATIE), Management and Silviculture of Tropical Forests, \\ 7170 Turrialba, Costa Rica
}

Received 28 May 1999; accepted 21 November 1999

\begin{abstract}
Seedlings of three commercial native tree species were planted under heterogeneous light and nutrient conditions in primary rainforest, secondary forest, and open pasture in Los Tuxtlas (Veracruz, Mexico). Management consisted of weeding around seedlings, and watering during the dry period. The objective was to find those natural growth conditions that maximize height growth in the first 2 years after transplantation from a nursery. Using stepwise multiple linear regression, the combined effect of varying canopy openness, leaf nutrients, initial seedling height, and seed mass on the plant height at the end of the study were analysed. The effect of the light environment differed clearly between species: the fruit species Pouteria sapota (Jacquin) H.E. Moore \& Stearn (Mamey) and Diospyros digyna Jacquin (Black Sapote) revealed an optimal canopy openness of 60 and 55\%, respectively, while the timber species Cedrela odorata Linnaeus (Spanish Cedar) grew best under maximum openness. Consequently, $P$. sapota and $D$. digyna are recommendable for an enrichment or shelterwood system in the forest, while $C$. odorata is recommendable as a reforestation species in the open. For $P$. sapota and D. digyna, plant height variation at the end of the study was also explained by the leaf zinc concentration, initial plant height, and in $P$. sapota by the seed mass and leaf calcium/magnesium ratio (for $C$. odorata, seed mass and nutrients had not been measured). The regression model indicated that considerable height increases are possible by optimizing these growth parameters within the encountered ranges. For $P$. sapota, average height growth after 24 months in the field could be increased 2.5 -fold, from $111 \mathrm{~cm}$ with average values to $280 \mathrm{~cm}$ with optimal values. For D. digyna, average height growth after 17 months could be increased 1.8 -fold, from 78 to $138 \mathrm{~cm}$. For C. odorata, the possible increase after 16 months was 2.7-fold, from 55 to $147 \mathrm{~cm}$. (C) 2000 Elsevier Science B.V. All rights reserved.
\end{abstract}

Keywords: Cedrela odorata; Diospyros digyna; Leaf nutrients; Light environment; Pouteria sapota; Rainforest management; Seedling growth

\footnotetext{
${ }^{*}$ Corresponding author. Tel.: +52-5-622-9045; fax: +52-5-622-9046

E-mail address: mricker@servidor.unam.mx (M. Ricker).
} 


\section{Introduction}

Forest managers need to decide about the best growth conditions for desired tree species. Light and nutrients are two major factors that determine tree growth. Plant physiologists have shown that plant species are adapted either to high or low levels of insolation (heliophytes and sciophytes, respectively; see Barbour et al., 1987: 368-371, Ashton and Berlyn, 1992). Shade-adapted plants (understory plants) fare poorly or not at all in direct sunlight, and sun-adapted plants (pioneers and canopy or overstory plants) do not thrive in the shade. Some Asian timber species in the genera Dipterocarpus, Shorea and Mesua require the type of shade conditions characteristic of mature forest for their early development (Ashton et al., 1992). Dacryodes excelsa Vahl (Tabonuco) and other timber species of Puerto Rican's 'Tabonuco forests' rarely establish well in open conditions (Devoe, 1992).

Fertilization is often recommendable in the establishment phase of plantations in tropical humid regions (Fölster and Khanna, 1997). Growth of higher plants depends in larger amounts on nine 'macronutrient' elements ( $\mathrm{N}, \mathrm{P}, \mathrm{K}, \mathrm{Ca}, \mathrm{Mg}, \mathrm{S}$ besides $\mathrm{C}, \mathrm{H}, \mathrm{O}$ ) and in lower amounts on eight 'micronutrient' elements (Fe, Mn, B, Mo, Cu, Zn, Cl, Co). Some plant species need or at least benefit from some additional elements (Na, F, I, Si, Ba, Se) (Brady, 1990, p. 14; Strasburger et al., 1983, pp. 333-334).

In this study we selected three native tree species of commercial interest in the Los Tuxtlas rainforest (Veracruz, Mexico). Seeds were germinated in a simple nursery, and the seedlings transplanted into weeded sites in 6 ha of primary and secondary forest, as well as in pasture. After 2 years of field measurements, we wanted to answer the following questions:

1. What is the optimal canopy openness above the seedlings of the fruit trees Pouteria sapota (Jacquin) H.E. Moore \& Stearn and Diospyros digyna Jacquin, as well as the timber species Cedrela odorata Linnaeus?

2. What nutrients limit growth in Pouteria sapota and Diospyros digyna in the field, and should therefore possibly be added via fertilization?

3. Is initial seedling height, at the time of transplanting into the field, important in determining later height?
4. Given the relatively large seeds of Pouteria sapota and Diospyros digyna, do seedlings from larger seeds grow better?

5. Finally, employing predictions from regression equations, to what degree could height growth be increased by optimising growth parameters?

\section{Site and species description}

The approximately $90 \mathrm{~km} \times 50 \mathrm{~km}$ geographic Los Tuxtlas region is a slightly mountainous region of volcanic origin in southern Veracruz near the Gulf coast (Martin-Del Pozzo, 1997). Our study was carried out at the 'Los Tuxtlas' tropical field station with its surrounding 640 ha-reserve, owned by the Universidad Nacional Autónoma de México (UNAM). The UNAM reserve is located in proximity to the Volcán de San Martín Tuxtla (1660 m altitude according to Andrle, 1964), about $30 \mathrm{~km}$ from the city of Catemaco on one side, and $4 \mathrm{~km}$ from the Gulf of Mexico on the other side $\left(95^{\circ} 04^{\prime}-09^{\prime} \mathrm{W}, 18^{\circ} 34^{\prime}-36^{\prime} \mathrm{N}\right)$. The reserve ranges in altitude between 150 and $700 \mathrm{~m}$. The area has a mean annual temperature of $25^{\circ} \mathrm{C}$ and a mean annual precipitation above $4000 \mathrm{~mm}$ (Bongers et al., 1988). The humid climate has some seasonality with a drier season from March to May, and a season of storms from November to February (see Soto and Gama, 1997). The vegetation represents 'tropical wet forest' according to Holdridge (1947) and 'tropical rainforest' according to Richards et al. (1996). The characteristics of the reserve vegetation are described in Ibarra-Manríquez et al. (1997a). A floristic checklist of 940 vascular plant species is found in IbarraManríquez and Sinaca (1995, 1996a, 1996b). IbarraManríquez et al. (1997b) discuss the plant species with market potential.

The three species employed in this study were Pouteria sapota (Mamey or Mamey Sapote, Sapotaceae), Diospyros digyna (Black Sapote, Ebenaceae), and Cedrela odorata (Spanish Cedar, Meliaceae). The genus Pouteria has been revised by Pennington (1990) in the Flora Neotropica. Pouteria sapota is a canopy tree, native to the evergreen and semi-evergreen tropical forests from south Mexico to Nicaragua in 0$500 \mathrm{~m}$ a.s.l. (Pennington, 1990). Good descriptions about the ecology and horticulture of P. sapota are found in Morton (1987) and in Oyen (1991); a Spanish 
summary is given in León (1987). Pouteria sapota is best known for its edible, avocado-sized fruits with their sweet, orange-colored pulp (see economic analysis in Ricker et al., 1999). The pulp is mainly eaten fresh, but also processed into ice-cream, yoghurt and cakes. The seed oil is traditionally used medicinally against hair-loss and in cosmetics. The timber is heavy, but also locally employed. Pouteria sapota is cultivated for its fruits from Florida to South America, as well as in the Caribbean (Morton, 1987; Hoyos, 1989) and in SE Asia (Oyen, 1991).

The genus Diospyros was treated taxonomically by Pacheco (1981) in the Flora de Veracruz. Diospyros digyna is a dioecious tree of tropical lowland forest, native from south Mexico to Costa Rica, and in the Carribean. The edible black pulp of the apple-sized fruits combines well in taste with oranges, and is thus often combined in deserts. The area of cultivation is about the same as for Pouteria sapota. León (1987); Morton (1987) and Ng (1991) are recommended as references. The species has also some medicinal and wood uses. The fruits of both $P$. sapota and D. digyna are found in the markets in Mexico City.

Cedrela odorata is found in the a taxonomic treatment by Pennington et al. (1981) in the Flora Neotropica. The internationally known tropical timber species is native from south Mexico to Argentina, and in the Caribbean. It is cultivated in the lowland tropics worldwide for its timber. The wood is maybe best known from its use for cigar boxes, but finds many other applications in furniture, doors, joinery etc. There are also medicinal uses. Much has been published about the species; here, the summaries in Lamprecht (1989) and Lemmens et al. (1995) are recommended.

\section{Methods}

Seeds of Pouteria sapota were collected in June 1994 from seven mother trees, and of Diospyros digyna in December 1994 from six mother trees; thus the seeds reflected somewhat local genetic diversity. The well-known species Cedrela odorata served mainly for comparison, and seeds were collected in May 1995 from only one mother tree. The seeds were germinated in a simple nursery in the research station. The nursery was shaded by vegetation and a fine plastic-grid. Commercial plastic bags of $20 \mathrm{~cm} \times$ $30 \mathrm{~cm}$ size were punched with a nail for drainage, and filled with about $1 \mathrm{~kg}$ of top soil (upper $10 \mathrm{~cm}$ ) without litter, from the nearby forest. One seed per bag was slightly pushed into the surface. The relatively large seeds of $P$. sapota and D. digyna were weighed before planting them. The germination rate was $91.6 \%$ for $P$. sapota ( $n=393$ planted seeds), and $42.0 \%$ for $D$. digyna $(n=400)$. The tiny seeds of $C$. odorata were neither weighed nor counted before their germination in the nursery.

The seeds of Pouteria sapota were planted in the nursery on 29-31 June 1994 and the seedlings transplanted into the field sites on 24-26 October 1994. The seeds of Diospyros digyna were planted on 7-9 December 1994, and the seedlings transplanted on 18-20 May 1995. For $C$. odorata, seeds were planted on 3-4 May 1995 and the transplantation was on 29-30 June 1995.

A total of 192 Pouteria sapota seedlings, 96 Diospyros digyna seedlings, and 39 Cedrela odorata seedlings were transplanted from the nursery into 6 ha of forest and pasture, located near the village of Lázaro Cárdenas but within the reserve area (not enough $C$. odorata seeds germinated to have 48 seedlings). The planting distance was approximately $10 \mathrm{~m}$. The 6 ha were subdivided into 24 quarter hectares of $50 \mathrm{~m} \times 50 \mathrm{~m}$ for the leaf nutrient analysis. Each quarter hectare had the following planting scheme when looking from above:

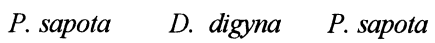

$$
\begin{aligned}
& \begin{array}{llll}
\text { D. digyna } & \text { P. sapota } & \text { C. odorata } \quad \text { P. sapota }
\end{array}
\end{aligned}
$$

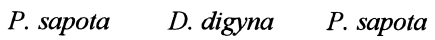

$$
\begin{aligned}
& \begin{array}{llll}
\text { D. digyna } & P \text {. sapota } & \text { C. odorata } & \text { P. sapota }
\end{array}
\end{aligned}
$$

The existing vegetation varied between mature primary forest, several-year-old secondary forest, and abandoned cattle pasture, thus providing a heterogenous light environment. Planting sites were prepared by some weeding of existing vegetation but no major disturbances were caused. Subsequent management consisted of watering in the first year during the dry months (10 times between 14 May and 9 June 1995; on 29 May and 31 May 1996), and weeding around each seedling every few weeks. No fertilization or pest management was carried out. A rust fungus on $D$. digyna that started in the nursery disappeared by itself after transplanting. Seedling 
height was measured monthly with a measurement tape for 16-24 months (depending on the species).

Soil analysis was carried out to describe the soil's major characteristics and for classification. Soil samples were taken near the planted seedlings in the upper $20 \mathrm{~cm}$ within each of the 24 quarter hectares, and mixed to obtain 24 composite samples. Our subsequent laboratory analysis gave the following results (average \pm standard error, $n=24$ ): $\mathrm{pH}=5.2 \pm 0.04$; total nitrogen content $=4.2 \pm 0.09 \mathrm{~g} / \mathrm{kg} ; \quad$ carbon $/$ nitrogen ratio $=10.6 \pm 0.28 ;$ available phosphorus $=3.5 \pm 0.69$ $\mathrm{mg} / \mathrm{kg}$; exchangeable potassium $=0.46 \pm 0.051 \mathrm{cmol}_{\mathrm{c}} /$ $\mathrm{kg}$ [centimols of positive charge $/ \mathrm{kg}$ ]; exchangeable calcium $=11.0 \pm 1.06 \mathrm{cmol}_{\mathrm{C}} / \mathrm{kg}$; exchangeable magnesium $=4.5 \pm 0.53 \mathrm{cmol}_{\mathrm{c}} / \mathrm{kg}$; exchangeable aluminium $=0.02 \pm 0.006 \mathrm{cmol}_{\mathcal{C}} / \mathrm{kg}$; effective cation exchange capacity $=16.3 \pm 1.59 \mathrm{cmol}_{\mathrm{c}} / \mathrm{kg}$. Three soil profile analyses within the six hectares lead to the classification as Mollic Andosol according to FAO (1994) and as Vitric Hapludand according to USDA (1992). Andosols, originated from volcanic ash, are generally productive soils for plant growth (Van Wambeke, 1992, pp. 207, 211-212).

\subsection{Light availability measurements}

Light was quantified by means of hemispheric photographs, as described by Rich (1989). Various authors have used the method successfully to characterize light environments in forests (e.g., Chan et al., 1986; Chazdon and Field, 1987; Canham et al., 1990; Rich, 1990; Whitmore et al., 1993; Zipperlen and Press, 1996). Hemispheric photographs do not take into account light quality (i.e., wave length composition), but rather characterize the light environment by quantifying the canopy cover above a plant. An openness of 0 corresponds to complete cover, and 1 to no cover at all. Photographs were taken with a Pentax camera and a Sigma F fisheye lens, using black-andwhite film (Kodak Tri X Pan, ASA 400). Photographs were taken on a tripod vertically towards the sky, over the apex of the seedling. One photograph was taken for each seedling site of Pouteria sapota in January 1995, and for all 336 seedling sites of the three species in January 1996. The film was developed by a commercial laboratory in Mexico City. The developed negatives were mounted one by one on a light table with an attached Canon video camera for digitization. The video camera was connected to a Hitachi black-andwhite monitor and a computer with a video digitizer and display adapter. The computer carried the software 'Canopy', developed and described by Rich (1989).

The light environment was not manipulated by management over the study period. For Pouteria sapota, the 1995 measurements were compared with the 1996 measurements to see how time-dependent these are. In part of the pasture area, regrowth of secondary vegetation had been considerable. Nevertheless, correlation between the two measurements was high, resulting in a Pearson correlation coefficient of 0.97 ( $n=188)$. This means that comparing plants relative to each other, the openness had changed little over the year.

\subsection{Leaf nutrient analysis}

Leaf nutrient concentrations can explain growth variation and lead to recommendations about fertilization, because they vary depending on the nutrient availability in the soil and precipitation (see Marschner, 1990, p. 406). The leaf nutrient analysis for calcium, iron, potassium, magnesium, nitrogen, sodium, phosphorus, manganese, and zinc was carried out for Pouteria sapota and Diospyros digyna, but not for Cedrela odorata. The seedlings of $C$. odorata were still small and taking off leaves would have damaged them. Also, the major focus of the study was on the former two species.

Leaf samples were collected in March 1996. The leaves of Pouteria sapota and Diospyros digyna were analysed separately. Two leaves were taken from each seedling. Depending on the number of leaves, their size, and healthiness, the 3/4th to 19/20th leaf was chosen (counting from the seedling apex). To reduce laboratory costs, the selected leaves from all seedlings of a given species and quarter hectare were mixed. For Pouteria sapota, there were eight seedlings per quarter hectare (minus any dead ones), and the collected leaves of these eight plants were combined into one sample. For D. digyna, there were four seedlings per quarter hectare (minus any dead ones). Each seedling of a given quarter hectare was assigned a common value, corresponding to that quarter hectare and species. For this reason, in Fig. 1 always several points have the same leaf zinc concentrations or calcium/ magnesium ratio at different heights. 
Collected leaves were put immediately into paper bags, and stored in a box cooled with ice to minimize respiration. That afternoon, they were washed with tap water, put into a stove, and dried until crisp at $65^{\circ} \mathrm{C}$ (deionised water was not available for washing). Then they were taken to the laboratory of the Geology Institute (UNAM) in Mexico City.

The leaves were milled in a steel mill. Calcination was performed at $480^{\circ} \mathrm{C}$ in a stove, and the ash uptaken in $0.5 \mathrm{M} \mathrm{HCl}$ (Pagel et al., 1982, p. 107). Calcium, magnesium, iron, manganese, and zinc were quantified by atomic absorption spectrophotometry. Potassium and sodium were quantified by flame photometry. Phosphorus was determined colorimetrically with the blue ammonium molybdate method, using ascorbic acid as reducing agent (Schlichting et al., 1995, p. 128). Separately, total nitrogen was determined by acid digestion, according to Kjeldahl (Schlichting et al., 1995, p. 165).

The complete laboratory analysis for each of the 48 composite leaf samples ( 24 quarter-hectares $\times 2$ species) and each of the nine elements was carried out twice to detect laboratory variation. Nested analysis of variance was carried out to detect significant variation of leaf nutrient concentrations among quarter hectares, hectares and species, given variation ('noise') in the laboratory methods $\left(Y=\mu+\alpha_{\mathrm{sp}}+B_{\mathrm{ha}}+B_{1 / 4 \mathrm{ha}}+B_{\mathrm{lab}}+\varepsilon\right.$, where $Y$ is the observed value, $\mu$ the parametric mean, $\alpha_{\mathrm{sp}}$ the treatment effect from distinct species, $B$ the random contribution, and $\varepsilon$ is the error term; Sokal and Rohlf, 1995, Chapter 10, with their BIOM 1988 statistics package and Rohlf and Sokal, 1995). The analysis showed that variation of the laboratory methods was sufficiently small to detect an added variance component in the leaf nutrient concentrations from 'quarter-hectares' (all elements) and from 'hectares' (all except Mn), as well as differences in the mean leaf nutrient concentrations between species (for $\mathrm{Ca}, \mathrm{K}$, $\mathrm{Mg}, \mathrm{N}, \mathrm{Mn}$ but not Na, P, Fe, Zn).

\subsection{Stepwise multiple linear regression}

Stepwise multiple linear regression, minimizing least squares, was carried out with the SYSTAT 6.0 for Windows statistics package (1996 by SPSS Inc., Chicago, USA). Only those plants entered the analysis, for which all data was available. The following regression model was used to explain seedling height of Pouteria sapota and Diospyros digyna in October 1996 in the field: FINAL-HEIGHT $=$ CONSTANT + OPENNESS + OPENNESS ${ }^{2}+$ INITIALHEIGHT + SEED-MASS + LEAF-CA+LEAF-FE + LEAF-K + LEAF-MG + LEAF-N + LEAF-NA + LEAF-P + LEAF-MN+LEAF-ZN+LEAF-CA/MG + LEAF-K/CA + LEAF-K/MG+LEAF-K/(MG+CA)+ LEAF-ZN/MG+LEAF-ZN/N+LEAF-ZN/P+LEAFZN/OPENNESS. For Cedrela odorata, the regression model was FINAL-HEIGHT $=$ CONSTANT + INITIAL-HEIGHT+OPENNESS + OPENNESS ${ }^{2}$. A linear multiple regression can include a quadratic term $\left(\mathrm{OPENNESS}^{2}\right)$, and in this way allows to check a curved regression line for a desired explanatory variable, such as relative canopy openness (see Fig. 1).

For leaf nutrient concentrations, there are three different ranges: a deficiency range, an adequate range, and a toxic range (Marschner, 1990, p. 391). In the deficiency range, there is an approximately linear growth response to an increase of the nutrient supply. In the adequate range, there is no response anymore to an increase of the nutrient supply. Finally, in the toxic range, growth is decreased with an increase of the nutrient supply. The objective here was to detect limiting nutrients in the first range, where a concentration increase leads to an approximately linear growth response.

The eight terms LEAF-CA/MG to LEAF-ZN/OPENNESS were included to detect interactions for the three elements calcium, magnesium, and zinc, which were or tended to be significant by themselves (the terms were recommended by Jorge D. Etchevers B., Colegio de Postgraduados, Montecillo, Mexico). Some interactions, such as between calcium and potassium, are well-known (Prevot and Ollagnier, 1960, p. 266). On some soils it is known that zinc deficiency is partly due to solar impact (Finck, 1982, p. 98), so that the leaf-zinc/ openness ratio was of interest. Finally, a number of studies report an interaction and optimal ratio between zinc and phosphorus (Timmer and Teng, 1990; Tomar et al., 1994; Karimian, 1995).

The coefficient of (multiple) determination $R^{2}$ was calculated as the explained sum of squares divided by the total sum of squares, and adjusted for the number of predictors $p$ (including the constant; SYSTAT, 1996 , p. 264): $R_{\text {adj }}^{2}=R^{2}-\left(1-R^{2}\right)(p-1) /(n-p)$. To obtain confidence intervals for the predicted average final-height, standard errors $\left(\mathrm{SE}_{Y}\right)$ had to be calcu- 
lated, multiplied with the $t_{(n-p)}$-value, and subtracted and added to the predicted average final-height. To calculate the standard error of the predicted averageheight at specified values of the independent variables $\left(X_{1}\right.$ to $X_{k}$ ), the following formula was employed (Sokal and Rohlf, 1995, p. 629): $\mathrm{SE}_{Y}=\left[s_{Y}\right]\left[1 / n+c_{11}\left(X_{1}-\right.\right.$ $\left.X_{1 \mathrm{Avg}}\right)^{2}+c_{22}\left(X_{2}-X_{2 \mathrm{Avg}}\right)^{2}+\ldots+c_{k k}\left(X_{k}-X_{k \mathrm{Avg}}\right)^{2}+2 c_{12}$ $\left(X_{1}-X_{1 \mathrm{Avg}}\right)\left(X_{2}-X_{2 \mathrm{Avg}}\right)+\ldots+2 c_{1 k}\left(X_{1}-X_{1 \mathrm{Avg}}\right)\left(X_{k}-\right.$ $\left.X_{k \mathrm{Avg}}\right)+\ldots+2 c_{23}\left(X_{2}-X_{2 \mathrm{Avg}}\right)\left(X_{3}-X_{3 \mathrm{Avg}}\right)+\ldots+$ $\left.2 c_{(k-1) k}\left(X_{k-1}-X_{(k-1) \mathrm{Avg}}\right)\left(X_{k}-X_{k \mathrm{Avg}}\right)\right]^{0.5}$. In this formula, $k$ is the number of independent variables in a model with a constant (six for Pouteria sapota in Table 2), $X_{i \text { Avg }}$ is the average value of the $i$ 's independent variable, and the $c_{i i}$ 's are the Gaussian multipliers. The SYSTAT 6.0 software provides in its output the unexplained standard deviation $s_{Y}$ (called there 'standard error of estimate'), but not the Gaussian multipliers. The BIOM 1988 statistics package provided a variance-covariance matrix in its routine MULREG, when recalculating the final regression model (Table 2) with this software. The numbers of this matrix were multiplied with $(n-1)$ to obtain the sum-of-squares \& sum-of-products matrix. This matrix was inverted with the Mathematica software (1991 by Wolfram Research Inc., Champaign, IL, USA) to obtain in this way the matrix of the Gaussian multipliers (see Sokal and Rohlf, 1995, p. 631).

In the case of Pouteria sapota and Diospyros digyna, the above formula for the standard error had to be employed even for average values, for which one can usually calculate the standard error as $s_{Y} / n^{0.5}$. The reason was that at average openness (for Pouteria sapota 0.305), the term OPENNESS ${ }^{2}$ has to be the value of this average-openness squared $\left(0.305^{2}=\right.$ 0.0930 ), which however deviates from the average OPENNESS $^{2}$ for the data set (0.1534).

For Cedrela odorata, the final regression model included only one independent variable (Table 2), and the above formula for the standard error simplified (Sokal and Rohlf, 1995, p. 471): $\mathrm{SE}_{Y}=\left[s_{Y}\right][1 /$ $\left.n+\left(X_{1}-X_{1 \mathrm{Avg}}\right)^{2} / \sum \mathrm{x}^{2}\right]^{0.5}$, where $\sum x^{2}$ is the sum of squares of the $X_{1}$-variable.

\section{Results}

The input data for the regression is summarised in Table 1. The table includes for the three species the averages, standard errors and ranges for the final height, relative canopy openness, initial seedling height, seed mass, and for the leaf nutrients as well as for the leaf nutrient interaction terms. The regression results for the three species are summarised in Table 2. The final regression equation is given for each species on the left, and can be used to calculate the expected seedling height in dependence of the explaining variables (see below). The next column gives the standard error for each regression coefficient. This data is followed in the third column by the standard coefficient (also called standard partial regression coefficients, b-primes or beta weights). The final column in Table 2 gives the two-tailed probability that the regression coefficient is zero. Almost all regression coefficients are highly significant, i.e., different from zero.

The standard coefficients give the rate of change in standard-deviation units of seedling height per one standard deviation unit of the corresponding $X$-variable (Sokal and Rohlf, 1995, pp. 613 and 614). When the number of data points is the same for the $X$ - and $Y$ variables (as here), then the standard coefficients can also be interpreted as the change in standard-error-ofthe-mean units, instead standard-deviation units. For example, for leaf-zinc in Pouteria sapota, the regression coefficient is 3.961 (Table 2), the standard error of the input data is 0.47 , and the standard error of the seedling height is 4.55 (Table 1), so that the standard coefficient in Table 2 is 0.41 [(3.961)(0.47)/4.55]. The standard coefficients help to interpret the impact of the $X$-variables on the $Y$-variable. For example, an increase of leaf-zinc by one standard error $(0.47 \mathrm{mg} /$ $\mathrm{kg}$ ) leads to an expected seedling height increase that is 0.41-times the standard error of final height $(4.55 \mathrm{~cm})$, i.e., $1.9 \mathrm{~cm}$. The variables in Table 2 are ordered by decreasing standard coefficients (subsequently to the constant).

Fig. 1 shows the regression results graphically, providing the prediction for one variable at a time while all other variables are held constant at their average values; the surrounding data points show the remaining unexplained variation ('error'). For Pouteria sapota, Table 2 and Fig. 1 show that height after 24 months is significantly explained by the leaf zinc concentration, leaf calcium-magnesium ratio, relative canopy openness, initial seedling height (at 0 months in the field), and mass of the 
Table 1

Measured final height and growth parameters of the planted tree seedlings (average \pm standard error [minimum to maximum])

\begin{tabular}{llll}
\hline & Pouteria sapota $(n=137)$ & Diospyros digyna $(n=72)$ & Cedrela odorata (n=18) \\
\hline FINAL-HEIGHT (cm) & $99.3 \pm 4.55[25.0$ to 306.0$]$ & $60.7 \pm 3.99[7.0$ to 158.0$]$ & $59.4 \pm 11.88[8.0$ to 200.0$]$ \\
Months in the field & 24 & 17 & 16 \\
OPENNESS & $0.305 \pm 0.0210[0.052$ to 0.864$]$ & $0.263 \pm 0.0262[0.037$ to 0.862$]$ & $0.291 \pm 0.0593[0.068$ to 0.776$]$ \\
INITIAL-HEIGHT (cm) & $29.9 \pm 0.81[7.0$ to 53.0$]$ & $12.8 \pm 0.39[5.7$ to 20.4$]$ & $5.9 \pm 0.67[1.7$ to 11.1$]$ \\
SEED-MASS $(\mathrm{g})$ & $40.2 \pm 0.82[14.8$ to 60.2$]$ & $2.1 \pm 0.04[1.4$ to 2.8$]$ & not measured \\
LEAF-CA $(\mathrm{mg} / \mathrm{g})$ & $8.24 \pm 0.087[6.70$ to 10.83$]$ & $12.82 \pm 0.191[8.43$ to 16.13$]$ & not measured \\
LEAF-FE $(\mathrm{mg} / \mathrm{g})$ & $0.37 \pm 0.019[0.10$ to 1.05$]$ & $0.25 \pm 0.019[0.06$ to 0.67$]$ & not measured \\
LEAF-K $(\mathrm{mg} / \mathrm{g})$ & $8.02 \pm 0.213[2.96$ to 12.87$]$ & $11.05 \pm 0.243[6.45$ to 16.35$]$ & not measured \\
LEAF-MG $(\mathrm{mg} / \mathrm{g})$ & $3.05 \pm 0.056[2.01$ to 4.40$]$ & $2.24 \pm 0.068[0.37$ to 3.05$]$ & not measured \\
LEAF-N $(\mathrm{mg} / \mathrm{g})$ & $20.7 \pm 0.20[17.3$ to 26.9$]$ & $18.8 \pm 0.32[14.8$ to 23.0$]$ & not measured \\
LEAF-NA $(\mathrm{mg} / \mathrm{g})$ & $1.07 \pm 0.032[0.47$ to 1.68$]$ & $0.88 \pm 0.041[0.32$ to 1.66$]$ & not measured \\
LEAF-P $(\mathrm{mg} / \mathrm{g})$ & $1.12 \pm 0.016[0.80$ to 1.45$]$ & $1.14 \pm 0.018[0.83$ to 1.46$]$ & not measured \\
LEAF-MN $(\mathrm{mg} / \mathrm{kg})$ & $36 \pm 0.8[20$ to 58$]$ & $144 \pm 4.6[89$ to 260$]$ & not measured \\
LEAF-ZN $(\mathrm{mg} / \mathrm{kg})$ & $13.4 \pm 0.47[6.9$ to 28.7$]$ & $14.0 \pm 0.53[6.6$ to 21.5$]$ & not measured \\
LEAF-CA/MG $(\mathrm{g} / \mathrm{g})$ & $2.8 \pm 0.05[2.0$ to 3.9$]$ & $6.9 \pm 0.76[4.0$ to 43.6$]$ & not measured \\
LEAF-K/CA $(\mathrm{g} / \mathrm{g})$ & $1.01 \pm 0.035[0.35$ to 1.84$]$ & $0.89 \pm 0.035[0.47$ to 1.94$]$ & not measured \\
LEAF-K/MG $(\mathrm{g} / \mathrm{g})$ & $2.9 \pm 0.12[0.8$ to 5.8$]$ & $5.7 \pm 0.48[2.1$ to 27.9$]$ & not measured \\
LEAF-K/MG+CA) & $0.74 \pm 0.027[0.25$ to 1.38$]$ & $0.76 \pm 0.028[0.38$ to 1.58$]$ & not measured \\
LEAF-ZN/MG (g/kg) & $4.4 \pm 0.12[2.2$ to 8.0$]$ & $6.8 \pm 0.40[3.2$ to 22.2$]$ & not measured \\
LEAF-ZN/N $(\mathrm{g} / \mathrm{kg})$ & $0.66 \pm 0.026[0.34$ to 1.55$]$ & $0.73 \pm 0.022[0.39$ to 1.05$]$ & not measured \\
LEAF-ZN/P $(\mathrm{g} / \mathrm{kg})$ & $12 \pm 0.4[6$ to 24$]$ & $13 \pm 0.5[5$ to 20$]$ & not measured \\
LEAF-ZN/OPENNESS & $88 \pm 5.8[8$ to 273$]$ & $103 \pm 8.8[10$ to 335$]$ & not measured \\
\hline
\end{tabular}

${ }^{\mathrm{a}} \mathrm{mg} / \mathrm{kg}$ at a relative canopy openness of 1 .

Table 2

Results of the stepwise multiple linear regression for the planted tree seedlings

\begin{tabular}{|c|c|c|c|}
\hline Regression equation & Standard error & Standard coefficient & Probability (two-tailed) \\
\hline \multicolumn{4}{|l|}{ Pouteria sapota ${ }^{\mathrm{a}}$} \\
\hline \multicolumn{4}{|l|}{ FINAL-HEIGHT= } \\
\hline-172.3 & 31.378 & 0 & 0.00000 \\
\hline +(3.961) (LEAF-ZN) & 0.73757 & 0.41 & 0.00000 \\
\hline +(31.87) (LEAF-CA/MG) & 8.8706 & 0.34 & 0.00046 \\
\hline +(242.5) (OPENNESS) & 73.330 & & 0.00122 \\
\hline -(200.4) (OPENNESS $\left.{ }^{2}\right)$ & 79.317 & 0.32 & 0.01270 \\
\hline +(1.444) (INITIAL-HEIGHT) & 0.40804 & 0.26 & 0.00056 \\
\hline +(1.065) (SEED-MASS) & 0.39469 & 0.19 & 0.00789 \\
\hline \multicolumn{4}{|l|}{ Diospyros digyna ${ }^{\mathrm{b}}$} \\
\hline \multicolumn{4}{|l|}{ FINAL-HEIGHT = } \\
\hline-55.57 & 17.922 & 0 & 0.00282 \\
\hline +(380.9) (OPENNESS) & 45.595 & & 0.00000 \\
\hline -(346.8) (OPENNESS $\left.{ }^{2}\right)$ & 53.833 & 0.56 & 0.00000 \\
\hline$+(2.455)(\mathrm{LEAF}-\mathrm{ZN})$ & 0.70258 & 0.33 & 0.00085 \\
\hline +(1.764) (INITIAL-HEIGHT) & 0.86417 & 0.17 & 0.04517 \\
\hline \multicolumn{4}{|l|}{ Cedrela odorata ${ }^{\mathrm{c}}$} \\
\hline $\begin{array}{l}\text { FINAL-HEIGHT }= \\
\quad(188.9)(\text { OPENNESS })\end{array}$ & 17.637 & 0.93 & 0.00000 \\
\hline
\end{tabular}

${ }^{a}$ After 24 months, adjusted $R^{2}=0.43, n=137$ seedlings, unexplained standard deviation $=40.23$.

${ }^{\mathrm{b}}$ After 17 months, adjusted $R^{2}=0.57, n=72$ seedlings, unexplained standard deviation $=22.29$.

${ }^{\mathrm{c}}$ After 16 months, $R^{2}=0.87, n=18$ seedlings, unexplained standard deviation=28.47; leaf nutrients and seed mass were not measured for this species. 

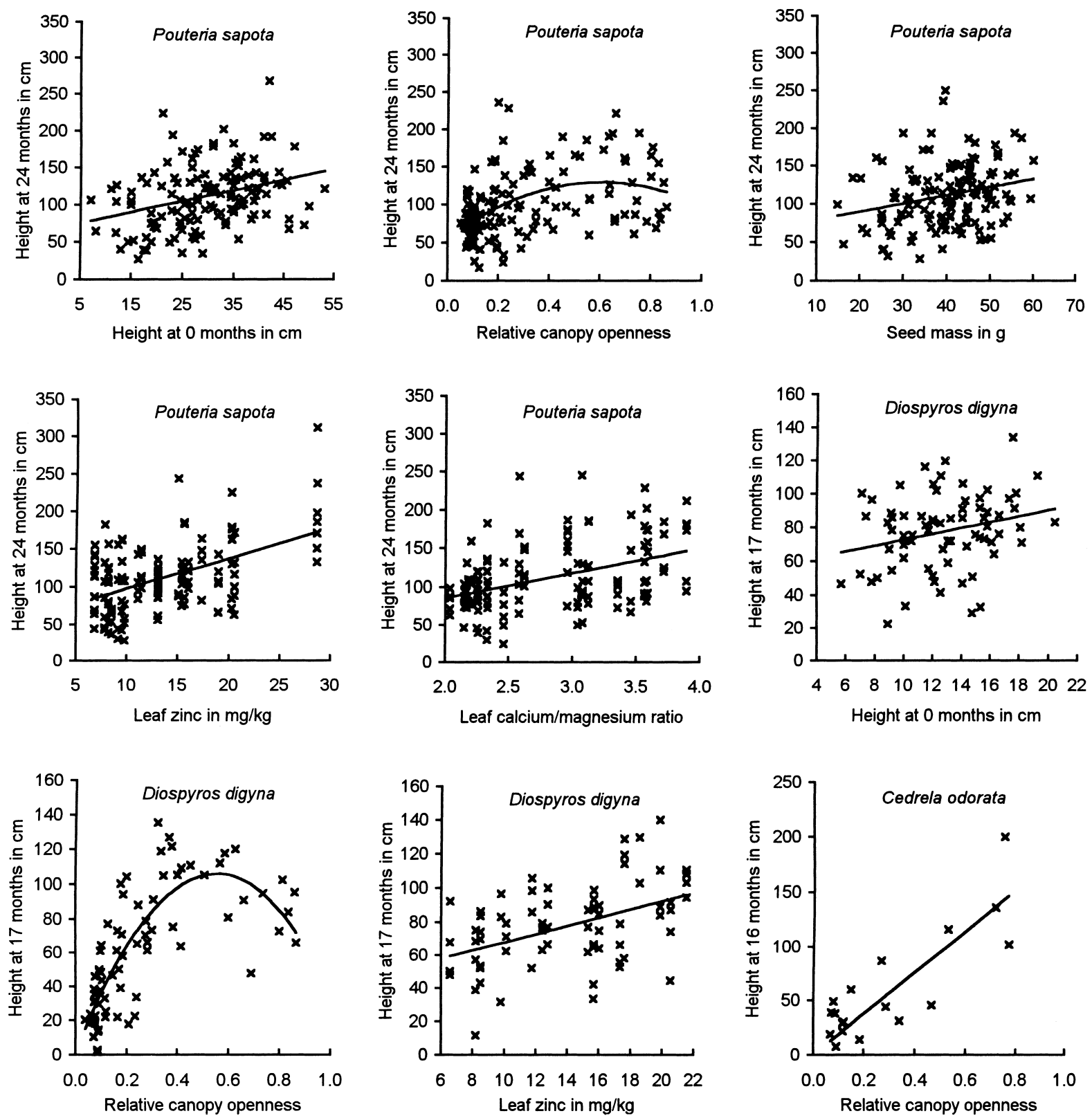

Fig. 1. Results of the stepwise multiple linear regression for the planted tree seedlings. For Pouteria sapota, five variables explained significantly height differences after 24 months in the field (see Table 2). In the case of Diospyros digyna, three variables were significant at 17 months, and for Cedrela odorata one variable at 16 months. In each graph, the prediction is for one variable at a time, while the other variables are held constant at their average value. The surrounding data points show the remaining unexplained variation.

planted seed. The other leaf nutrient concentrations were not significant. Table 3 uses the regression equations from Table 2 and input parameters from Table 1 to calculate how much average height growth could be improved by optimizing the growth conditions. With all growth parameters being at their average values in the regression equation, the predicted average height for Pouteria sapota after 24 
Table 3

Predicted average height (95\% confidence intervals) under average and optimised growth parameters, employing the regression equations from Table 2

\begin{tabular}{|c|c|c|c|}
\hline & Average parameters & Optimised parameters & Ratio \\
\hline Pouteria sapota (at 24 months) & $111 \mathrm{~cm}(104-119)^{\mathrm{a}}$ & $280 \mathrm{~cm}(224-336)^{\mathrm{b}}$ & 2.5 \\
\hline Diospyros digyna (at 17 months) & $78 \mathrm{~cm}(70-85)^{\mathrm{c}}$ & $138 \mathrm{~cm}(116-160)^{\mathrm{d}}$ & 1.8 \\
\hline Cedrela odorata (at 16 months) & $55 \mathrm{~cm}(41-69)^{\mathrm{e}}$ & $147 \mathrm{~cm}(115-178)^{\mathrm{f}}$ & 2.7 \\
\hline
\end{tabular}

${ }^{\mathrm{a}} \mathrm{LEAF}-\mathrm{ZN}=13.4 \mathrm{mg} / \mathrm{kg}$, LEAF-CA/MG=2.8, OPENNESS=0.305, INITIAL-HEIGHT=29.9 cm, SEED-MASS=40.2 g (average values as given in Table 1), standard error $=3.71, n=137$.

${ }^{\mathrm{b}} \mathrm{LEAF}-\mathrm{ZN}=28.7 \mathrm{mg} / \mathrm{kg}$, LEAF-CA/MG $=3.9$, OPENNESS $=0.605$, INITIAL-HEIGHT $=53.0 \mathrm{~cm}$, SEED-MASS $=60.2 \mathrm{~g}$ (maximum values as given in Table 1, except that openness is optimised as explained in text), standard error $=28.32, n=137$.

${ }^{c}$ OPENNESS $=0.263$, LEAF-ZN $=14.0 \mathrm{mg} / \mathrm{kg}$, INITIAL-HEIGHT $=12.8 \mathrm{~cm}$, standard error $=3.69, n=72$.

${ }^{\mathrm{d}}$ OPENNESS $=0.549$, LEAF-ZN $=21.5 \mathrm{mg} / \mathrm{kg}$, INITIAL-HEIGHT $=20.4 \mathrm{~cm}$, standard error $=11.10, n=72$.

${ }^{\mathrm{e}}$ OPENNESS $=0.291$, standard error $=6.71, n=18$.

${ }^{\mathrm{f}}$ OPENNESS $=0.776$, standard error $=14.90, n=18$.

months in the field is $111 \mathrm{~cm}[-172.3+(3.961)(13.4)$ $+(31.87)(2.8)+(242.5)(0.305)-(200.4)\left(0.305^{2}\right)+$ $(1.444)(29.9)+(1.065)(40.2)$. The $95 \%$ confidence interval is $104-119 \mathrm{~cm}$ [111.3土(3.71)(1.978)]. This compares to an actual average height of $99.3 \mathrm{~cm}$ in the field (Table 1).

Next, one can see what is the predicted height when optimizing the growth parameters. The openness is optimised by taking the first derivative of the prediction equation, setting it equal to zero, and solving for the openness: $d$ HEIGHT/ $d$ OPENNESS $=242.5-(2)$ $(200.4)($ OPENNESS $)=0 \Rightarrow$ OPENNESS $=0.605$. The optimal canopy openness for Pouteria sapota plants over their first 24 months is $60.5 \%$. All other variables are optimised by maximizing them within the measured range of the input data. Extrapolation linearly into new ranges is not recommendable, because a linear plant response is not empirically confirmed. Employing the optimal openness and maximum measured values for the other variables (Table 1), the predicted average height of $P$. sapota after 24 months in the field is $280 \mathrm{~cm}$. The $95 \%$ confidence interval is $224-336 \mathrm{~cm}$. This compares to an actual height of $306 \mathrm{~cm}$ for the largest individual (statistically an outlier), and $229 \mathrm{~cm}$ of the second-largest in the field. Thus, the calculated optimised average height seems not to be unrealistically 'out of range'.

The predicted average height with optimal values for the growth parameters is 2.5-times the predicted average height with average values for the growth parameters $(280 / 111)$. In conclusion, by optimizing the growth parameters 'leaf zinc concentration', 'leaf calcium/magnesium ratio', 'relative canopy openness', 'initial seedling height', and 'seed mass', one should have been able to increase height growth 2.5fold during the first 24 months in the field.

The same sequence of calculations and comparisons can be carried out for the other two species. The canopy openness, leaf zinc concentration, and initial seedling height (at 0 months in the field) were significant for Diospyros digyna in explaining height after 17 months, but the mass of the planted seed was not significant (Table 2, Fig. 1). The predicted average height for Diospyros digyna after 17 months is $78 \mathrm{~cm}$ (Table 3). This compares to an actual average height in the field of $60.7 \mathrm{~cm}$ with heterogeneous values for the growth parameters (Table 1).

Optimizing the relative canopy openness for Diospyros digyna in the same way as for Pouteria sapota, results in $54.9 \%$. This is a little bit lower than the $60.5 \%$ for Pouteria sapota. Also, Fig. 1 shows that the optimum is more pronounced for $D$. digyna, while $P$. sapota accepts relatively well openness values that exceed the optimum. Using the optimal openness together with the maximum values for the leaf zinc concentration and initial seedling height (Table 1), the predicted average height of Diospyros digyna after 17 months in the field is $138 \mathrm{~cm}$ (Table 3). This compares to the maximum height of an individual in the field of $158.0 \mathrm{~cm}$ (Table 1). The predicted average height with optimal values for the growth parameters is 1.8-times the predicted average height when using the average values for the growth parameters (Table 3). By optimizing the growth parameters 'relative canopy open- 
ness', 'leaf zinc concentration', and 'initial seedling height', one should have been able to increase height growth 1.8-fold during the first 17 months in the field.

For Cedrela odorata seedlings, neither leaf nutrient analysis nor seed mass measurements were carried out. Thus, the only growth parameters tested were canopy openness and initial seedling height. The quadratic term $\left(\mathrm{OPENNESS}^{2}\right)$ resulted to be not significant, so that height after 16 months was linearly dependent on canopy openness (Fig. 1). Initial seedling height was not significant (note in Table 3 that they were still very small at 0 months). The average value for the relative canopy openness in the field was 0.291 (Table 1). This results in a predicted average height of $55 \mathrm{~cm}$ after 16 months in the field (Table 3). This compares to an actual average height of $59 \mathrm{~cm}$ in the field (Table 1). Since the quadratic term has fallen out, the optimal relative canopy openness would be 1 , i.e. complete openness. However, the maximum observed openness was 0.776 (Table 1). Because the range between 0.776 and 1 was not tested empirically, 0.776 was used as the maximum openness. The predicted average height with this maximum openness for Cedrela odorata after 16 months in the field is $147 \mathrm{~cm}$ (Table 3). This compares to the maximum height of an individual in the field of $200.0 \mathrm{~cm}$ (Table 1). The predicted average height with maximum openness is 2.7-times the height when using average openness. By maximizing relative canopy openness, one should have been able to increase height growth 2.7-fold during the first 16 months in the field.

\section{Discussion}

Returning to the questions posed in the introduction, these can be answered as follows:

1. The optimal canopy openness above the seedlings of Pouteria sapota and Diospyros digyna was 60 and $55 \%$, respectively. For Cedrela odorata it was above $78 \%$ and might be $100 \%$.

2. Natural variation in the leaf-zinc concentration explained growth variation in Pouteria sapota and Diospyros digyna in these plantings (leaf nutrients were not measured for Cedrela odorata). In addition, in $P$. sapota a higher leaf calcium/ magnesium ratio explained larger plant height after 24 months. Consequently, zinc and calcium fertilisation may be recommendable.

3. For both Pouteria sapota and Diospyros digyna, initial seedling height (at 0 months in the field) explained significantly final seedling height (at 24 and 17 months, respectively). Initial seedling height was not significant in Cedrela odorata.

4. Larger seeds explained larger plant height after 24 months for Pouteria sapota, but not for Diospyros digyna (seeds were not measured for Cedrela odorata).

5. The regression equations (Table 2) revealed that by optimising the tested growth parameters within the encountered ranges, the average height of Pouteria sapota after 24 months in the field could be increased 2.5 -fold, from $111 \mathrm{~cm}$ with average values to $280 \mathrm{~cm}$ with optimal values. For Diospyros digyna, average height after 17 months could be increased 1.8 -fold, from 78 to $138 \mathrm{~cm}$. For Cedrela odorata the possible increase after 16 months is 2.7 -fold, from 55 to $147 \mathrm{~cm}$.

The results confirm that species differ in their light demands, and that there can be excessive light levels for tree seedlings of some species. For example, in a 10-year-old secondary forest in Veracruz (Mexico), Cordia alliodora (Ruíz \& Pavón) Chamisso, Swietenia macrophylla King, and Brosimum alicastrum Swartz also showed highest growth rates at $68 \%$ rather than $100 \%$ light transmission into the understory (Ramos and del Amo, 1992). Our result that Cedrela odorata is a strong light-demander is a confirmation of what is known from the literature (Pennington et al., 1981, p. 376).

It should be noted that a relative canopy openness of over $50 \%$ is rarely found in natural evergreen rain forest. Values of less than $5 \%$ full light have been reported for the understory (Chazdon and Fetcher, 1984; Ashton, 1992). Considerable manipulation of a primary forest's canopy is necessary to reach values of around $60 \%$. This dependence of seedlings on light levels that are reached only in large gaps, explains why under natural conditions species such as Pouteria sapota and Diospyros digyna are rare (often less than 1 tree per hectare). On the other hand, it provides a justification to argue that under management that minimises the obstacles of establishment under a 
favorable light environment, enrichment plantings are expected to prosper.

Variation in the leaf zinc concentrations explained variation in height growth of the seedlings of Pouteria sapota and Diospyros digyna. Zinc deficiency is not unusual. In Citrus trees, zinc deficiency is the most common deficiency after nitrogen deficiency. In intensive management it has also been observed in coffee plantations in Brazil, Costa Rica, and India (Pagel et al., 1982, pp. 215-218). There are other examples where studies showed that zinc fertilization increased plant growth: in cotton plants, zinc fertilization slightly increased growth and improved cotton quality (Li et al., 1991). In banana, combined application of zinc with copper and boron lead to maximum yield per hectare (Ghanta and Mitra, 1993). And in tomato, the combined fertilisation with zinc, manganese, iron, and boron resulted in maximum yield (Bose and Tripathi, 1996).

Zinc acts either as a metal component on enzymes (alcohol dehydrogenase, $\mathrm{Cu}-\mathrm{Zn}$ superoxide dismutase, carbonic anhydrase, RNA polymerase), or as a regulatory cofactor of a number of enzymes (Marschner, 1990, pp. 300-301). In zinc-deficient wheat, leaves show a decreased chlorophyll concentration and an increased accumulation of sugars; net photosynthesis is decreased (Sharma et al., 1992).

Interesting was the finding that the leaf calcium/ magnesium ratio significantly explained variation in height growth of Pouteria sapota. This leads to two conclusions. First, fertilisation with calcium is expected to have a positive effect. Calcium deficiency is known from fruit tree plantations, and is relatively common in tropical soils (Schachtschabel et al., 1982, p. 211). In the plant, calcium stabilizes cell membranes by bridging phosphate and carboxylate groups of phospholipids and proteins (Marschner, 1990, p. 249).

Second, fertilisation with magnesium without fertilizing calcium is expected to have a negative effect. Interaction between calcium and magnesium has also been reported by Spiers (1993a) in blueberrry and by Spiers (1993b) in raspberry. In contrast to calcium, which is an activator of only a few enzymes, magnesium increases the activity of many enzymes (Marschner, 1990, p. 249). Magnesium is the central atom of the chlorophyll molecule, but this role involves only about $30 \%$ of the total plant magnesium content, and a high proportion is involved in the regulation of cellular $\mathrm{pH}$ and the cation-anion balance (Marschner, 1990, p. 236). Calcium and magnesium can compete on binding sites (Marschner, 1990, p. 250), which might explain the antagonism found in our work.

According to 'Liebig's minimum law', there is only one limiting nutrient element at a time, and first one needs to fertilize this nutrient element before another becomes limiting (Finck, 1982, p. 229). In our work, zinc could be considered to be this limiting nutrient. However, this concept should not be taken too rigorously. The importance of antagonisms, synergisms, and a balanced equilibrium between nutrients has long been known from fertilisation experiments (Prevot and Ollagnier, 1960). It is confirmed here by our finding of the calcium/magnesium ratio being a limiting factor in addition to zinc in Pouteria sapota.

Initial seedling height, at the time of transplanting, explained significantly the seedling height of Pouteria sapota after 24 months and of Diospyros digyna after 17 months. Larger height at establishment provides a long-lasting positive effect on growth. In P. sapota, the regression equation (Table 2) showed that an additional centimeter of initial seedling height is expected to lead to an additional $1.444 \mathrm{~cm}$ after 24 months. The effect was stronger in P. sapota (standard coefficient 0.26 in Table 2) than in D. digyna (0.17), and not significant in Cedrela odorata. These differences between species are probably due to the larger variation of absolute initial seedling height in $P$. sapota (range 7-53 cm, Table 1), compared to D. digyna (6$20 \mathrm{~cm})$ and $C$. odorata $(2-11 \mathrm{~cm})$.

In Pouteria sapota, large seeds favored height growth after germination. In the literature we found two studies that report correlation between seed mass and seedling growth for Douglas Fir at 2 years age (St. Clair and Adams, 1991) and for two oak species at 6 months age (Bonfil, 1998). From this result, one can draw three types of conclusions for management: first, for establishing plantings one could obtain a large pool of seeds and select the largest ones. Second, one could try to breed varieties with larger seeds. Third, one could interpret the effect of large seeds to be a type of initial fertilization, and rather than using large seeds one could fertilize at the time of planting, which is a common technique in tree production.

It is interesting that in Pouteria sapota, both seed mass and initial seedling height were statistically 
significant; the Pearson correlation coefficient for the data between seed mass and initial seedling height in P. sapota was 0.38 , which statistically is highly significant $(n=137)$. Larger seeds are not only expected to lead to larger seedlings at the time of transplantation, which leads by itself to a larger height, but they contribute additionally to an increased height after 24 months. An additional gram of seed mass is expected to lead to an additional $1.065 \mathrm{~cm}$ of height after 24 months (Table 2), on top of the effect achieved by the larger initial seedling height.

Considerable height variation remained unexplained in all species: the proportion of the unexplained sum of squares $\left(1-R^{2}\right)$ was 0.57 for Pouteria sapota, 0.43 for Diospyros digyna, and 0.13 for Cedrela odorata. In C. odorata, the effect of canopy openness is stronger than in the other two species (standard coefficient $=0.93$ in Table 2); this causes the coefficient of determination $R^{2}$ to be large even without taking leaf nutrients into account. In $P$. sapota and D. digyna, a higher coefficient of determination $R^{2}$ could probably be achieved by analysing leaf nutrient data per plant, rather than mixing leafs from all plants of a given species per quarter hectare; the laboratory costs would of course be higher. Furthermore, height variation in the first 2 years may be due to genetic variation between seedlings, which could best be analysed in the future by developing and planting different clones in varying environmental conditions (see Kolb and Steiner, 1989).

An additional important factor for explaining height growth variation in all species could be water availability. Water availability for seedlings was not measured in our study. However, height measurements were carried out monthly, and the plants' relative monthly height growth can be correlated statistically with the corresponding monthly precipitation and monthly average of the daily minimum and maximum temperatures. Carrying out these nine correlation analyses, only two resulted to be statistically significant: For Pouteria sapota, the seedling's relative monthly height growth was correlated with minimum daily temperature $(r=0.636, n=24)$, and to a lesser extent with the daily maximum temperature. The seedlings of this species seem to grow better at higher temperature. Precipitation was not significantly correlated with relative growth for any of the three species (note that precipitation was not significantly corre- lated with temperature; also note that we watered in a few dry weeks). There are certainly measurable effects on seedling development resulting from strong differences in water availability between seedlings, and from prolonged dry periods (Fisher et al., 1991).

How much annual growth is effected by these differences in tropical forest with high precipitation remains to be studied in more detail (Burslem, 1996). Wright (1991) in a study of seven shrub species on Barro Colorado Island (Panama; 2,600 mm mean annual precipitation) concluded that his results were consistent with the hypothesis that "water stress constraints the timing of growth while only rarely limiting total annual growth'.

To compare the growth potential between the three species, one can calculate the expected annual height increment in the first year under optimal conditions via interpolation. Pouteria sapota is expected to have in the first year an average increment of $113 \mathrm{~cm}$ [(279.7-53.0)(12/24)], Diospyros digyna $83 \mathrm{~cm}$ [(137.8-20.4)(12/17)], and Cedrela odorata $106 \mathrm{~cm}$ [(146.6-5.9)(12/16)]. Note that the leaf nutrients for C. odorata could not be optimised for this calculus, because they were not included in the regression. Nevertheless, it shows that $P$. sapota grows comparably fast and may be able to compete with the popular timber species $C$. odorata with its lighter wood, while $D$. digyna grows slower.

The question rises what variables should be managed to achieve the greatest possible impact on height growth. This question can be considered from a statistical and from an economic viewpoint. From a statistical viewpoint, one can look on the standard coefficients for each independent variable in Table 2. Subsequently to the constant, the independent variables are ordered according to decreasing standard coefficient. As explained above in the results, the standard coefficients indicate how many standard errors does the seedling height change with a onestandard-error-change of the independent variable. In the case of Pouteria sapota, the zinc concentration and the calcium/magnesium ratio have the greatest impact, while in Diospyros digyna the relative canopy openness has the greatest impact. The differences between standard coefficients are notable but not huge, ranging from 0.17 for initial seedling height of $D$. digyna to 0.93 for relative canopy openness for Cedrela odorata. 
From an economic viewpoint, one has to consider what management is cost-effective and practical. Managing the light environment via partial cuttings of an existing canopy is quick and cheap. Fertilizing with soil fertilizers or foliar sprays is also relatively quick and cheap. A disadvantage of these two actions is that they may have an impact on the forest environment that conservationists could oppose. However, compared to conversion of an existing forest to cattle pasture, the proposed management impact remains rather moderate.

In contrast, selection and breeding of large seeds and large seedlings do not have an obvious management impact on the forest site, but may be costlier and could only be a long-term goal. Furthermore, the first priority for selection in fruit species is generally for tasty fruit varieties, and only subsequently for seed and seedling size; this is an important consideration for Pouteria sapota, which presents much variation of fruit quality.

Finally the question comes up, what these results for seedlings and young trees mean for later ages, i.e., how does growth in the first 2 years correlate with later growth? One way to gain more insight into this problem is to analyse the correlation between the first year and second year height increment in Pouteria sapota. The Pearson correlation coefficient in this case is 0.71 , which statistically is highly significant $(n=137)$. Apparently, there was a strong trend that a plant that was large after 1 year, was again a large plant after 2 years. In general, one would expect a plant that grows well in the first 2 years to continue its good performance in subsequent years, if the environmental conditions don't change.

Optimizing management from a biological viewpoint may include not only maximizing height growth, but also maximizing survivorship and minimizing pest attacks. Survivorship was $83 \%$ after 24 months for Pouteria sapota, $86 \%$ after 17 months for Diospyros digyna, and $46 \%$ after 16 months for Cedrela odorata. A relatively uniform mortality of less than $20 \%$ for $P$. sapota and $D$. digyna after planting and during the first 2 years can be accounted for with acceptable effort by initial overstocking. More problematic was the 54\% mortality of $C$. odorata after 16 months, which on this site was clearly a more delicate species. Of this species, 39 seedlings were planted, of which 21 died and 18 survived. Was mortality predominant on obscure sites with low canopy openness, where growth was also low? Canopy openness had been measured for all 39 seedlings, including those ending up dead, so that two groups could be formed: The dead $C$. odorata seedlings had an average canopy openness of 0.156 (Standard Error $=0.0450, n=21$ ), while the surviving C. odorata seedlings had an average canopy openness of $0.291(0.0486,18)$. In a single-classification analysis-of-variance, these averages are significantly different at the 5\% level. Management that promotes growth (here maximum openness for $C$. odorata) apparently promotes also survivorship.

In conclusion, considerable height growth increases can be expected from optimizing growth parameters such as canopy openness, nutrient supply, initial seedling height and seed mass. Given their distinct light requirements, Pouteria sapota and Diospyros digyna are recommendable for an enrichment or shelterwood system, while Cedrela odorata is recommendable as a reforestation species in the open.

\section{Acknowledgements}

This study was part of a Ph.D. Thesis of the first author at Yale University's School of Forestry and Environmental Studies (New Haven, Connecticut, USA). Thanks go to Robert O. Mendelsohn (Yale University) and Douglas C. Daly (The New York Botanical Garden, New York, USA) for their advise. The field work was financially supported by the Programa Universitario de Alimentos under Ernesto Moreno M. (Universidad Nacional Autónoma de México, Mexico City). Guillermo Ángeles A. and Miguel A. Sinaca C. (Estación de Biología 'Los Tuxtlas', Veracruz, Mexico) supported greatly the field work. Rosario Pilar I. and Pedro Avilés helped in the laboratory work for the leaf nutrient analysis.

\section{References}

Andrle, R.F., 1964. A biogeographical investigation of the Sierra de Tuxtla in Veracruz, Mexico, Ph.D. Thesis. Louisiana State University, Department of Geography and Anthropology, Louisiana, USA, 235 pp.

Ashton, P.M.S., 1992. Some measurements of the microclimate within a Sri Lankan tropical rainforest. Agric. For. Meteorol. 59, 217-235. 
Ashton, P.M.S., Berlyn, G.P., 1992. Leaf adaptations of some Shorea species to sun and shade. New Phytol. 121, 587-596.

Ashton, P.M.S., Gunatilleke, C.V.S., Gunatilleke, I.A.U.N., 1992. A shelterwood method of regeneration for sustained timber production in Mesua-Shorea forest of southwest Sri Lanka. In: Erdelen, W., Preu, C., Ishwaran, N., Santiapillai, C. (Eds.), Ecology and Landscape Management in Sri Lanka: Conflict or Compromise? Verlag Josef Margraf Scientific, Hamburg, Germany, pp. 203-229.

Barbour, M.G., Burk J.H., Pitts, W.D., 1987. Terrestrial Plant Ecology. The Benjamin/Cummings Publishing Company, Menlo Park, California, USA, $634 \mathrm{pp}$.

Bonfil, C., 1998. The effects of seed size, cotyledon reserves, and herbivory on seedling survival and growth in Quercus rugosa and Q. laurina (Fagaceae). Am. J. Bot. 85, 79-87.

Bongers, F., Popma, J., Meave del Castillo, J., Carabias, J., 1988. Structure and floristic composition of the lowland rain forest of Los Tuxtlas, Mexico. Vegetatio 74, 55-80.

Bose, U.S., Tripathi, S.K., 1996. Effect of micronutrients on growth yield and quality of tomato cv. Pusa Ruby in M.P. Crop Res. (Hisar) 12, 61-64.

Brady, N.C., 1990. The Nature and Properties of Soils. MacMillan Publishing Company, New York, USA, 621 pp.

Burslem, D.F.R.P., 1996. Differential responses to nutrients, shade and drought among tree seedlings of lowland tropical forest in Singapore. In: Swaine, M.D. (Ed.), The Ecology of Tropical Forest Tree Seedlings. UNESCO, Paris, France, and The Parthenon Publishing Group, New York, USA, pp. 211-244.

Canham, C.D., Denslow, J.S., Platt, W.J., Runkle, J.R., Spies, T.A., White, P.S., 1990. Light regimes beneath closed canopies and tree-fall gaps in temperate and tropical forests. Can. J. For. Res. 20, 620-631.

Chan, S.S., McCreight, R.W., Walstad, J.D., Spies, T.A., 1986. Evaluating forest vegetative cover with computerized analysis of fisheye photographs. For. Sci. 32, 1085-1091.

Chazdon, R.L., Fetcher, N., 1984. Light environments of tropical forests. In: Medina, E., Mooney, H.A., Vázquez-Yánes, C. (Eds.), Physiological Ecology of Plants of the Wet Tropics. Dr. W. Junk Publishers, The Hague, The Netherlands, pp. 27-36.

Chazdon, R.L., Field, C.B., 1987. Photographic estimation of photosynthetically active radiation: evaluation of a computerized technique. Oecologia (Berlin) 73, 525-532.

Devoe, N.N., 1992. Regeneration from seed under a range of canopy consitions in tropical wet forest, Puerto Rico. In: Kelty, M.J., Larson, B.C., Oliver, C.D. (Eds.), The Ecology and Silviculture of Mixed-Species Forests. Kluwer Academic Publishers, Dordrecht, The Netherlands, pp. 81-100.

FAO, 1994. Soil Map of the World - Reprint of World Soil Resources Report 60 (FAO, Rome, 1988) with Corrections. Food and Agricultural Organization of the United Nations, Rome, Italy, $140 \mathrm{pp}$

Finck, A., 1982. Fertilizers and Fertilization - Introduction and Practical Guide to Crop Fertilization. Verlag Chemie, New York, USA, $438 \mathrm{pp}$.

Fisher, B.L., Howe, H.F., Wright, S.J., 1991. Survival and growth of Virola surinamensis yearlings: water augmentation in gap and understory. Oecologia 86, 292-297.
Fölster, H., Khanna, P.K., 1997. Dynamics of nutrient supply in plantation soils. In: Nambiar, E.K.S., Brown, A.G. (Eds.), Management of Soil, Nutrients and Water in Tropical Plantation Forests. ACIAR, Canberra, Australia, pp. 338-378.

Ghanta, P.K., Mitra, S.K., 1993. Effect of micronutrients on growth, flowering, leaf nutrient content and yield of banana cv. Giant Governor. Crop Res. (Hisar) 6, 284-287.

Holdridge, L.R., 1947. Determination of world plant formations from simple climatic data. Science 105, 367-368.

Hoyos F.J., 1989. Frutales en Venezuela. Sociedad de Ciencias Naturales La Salle (Monografía 36), Caracas, Venezuela, 375 pp.

Ibarra-Manríquez, G., Sinaca C., S., 1995. Lista florística comentada de la Estación de Biología Tropical 'Los Tuxtlas', Veracruz, Méxicon. Rev. Biol. Trop. 43, 75-115.

Ibarra-Manríquez, G., Sinaca C., S., 1996a. Estación de Biología Tropical 'Los Tuxtlas', Veracruz, Mexico: Lista florística comentada (Mimosaceae a Verbenaceae). Rev. Biol. Trop. 44, 41-60.

Ibarra-Manríquez, G., Sinaca C., S., 1996b. Lista comentada de la Estación de Biología Tropical 'Los Tuxtlas', Veracruz, Mexico (Violaceae-Zingiberaceae). Rev. Biol. Trop. 44, 427-447.

Ibarra-Manríquez, G., Martínez-Ramos, M., Dirzo, R., NúñezFarfán, J., 1997a. La vegetación. In: González S., E., Dirzo, R., Vogt, R.C. (Eds.), Historia natural de Los Tuxtlas. Universidad Nacional Autónoma de México, México D.F., Mexico, pp. 6185.

Ibarra-Manríquez, G., Ricker, M., Ángeles, G., Sinaca C., S., Sinaca C., M.A., 1997b. Useful plants of the Los Tuxtlas rain forest (Veracruz, Mexico): considerations of their market potential. Econ. Bot. 51, 362-376.

Karimian, N., 1995. Effect of nitrogen and phosphorus on zinc nutrition of corn in a calcareous soil. J. Pl. Nutr. 18, 22612271.

Kolb, T.E., Steiner, K.C., 1989. Genetic variation among and within single-tree progenies of Northern Red Oak. For. Sci. 35, 251-256.

Lamprecht, H., 1989. Silviculture in the Tropics. Deutsche Gesellschaft für Technische Zusammenarbeit (GTZ) GmbH, Eschborn, Germany, 296 pp.

Lemmens, R.H.M.J., Soerianegara, I., Wong, W.C. (Eds.), 1995. Plant Resources of South-East Asia 5(2) - Timber Trees: Minor Commercial Timbers. Backhuys Publishers, Leiden, The Netherlands. $655 \mathrm{pp}$.

León, J., 1987. Botánica de los cultivos tropicales. Instituto Interamericano de Cooperación para la Agricultura, San José, Costa Rica, 445 pp.

Li, J., Zhou, M., Pessarakli, M., Stroehlein, J.L., 1991. Cotton response to zinc fertilizer. Commun. Soil Sci. Pl. Analysis 22, 1689-1700.

Marschner, H., 1990. Mineral Nutrition of Higher Plants. Academic Press, London, UK, 674 pp.

Martin-Del Pozzo, A.L., 1997. Geología. In: González S., E., Dirzo, R., Vogt, R.C. (Eds.), Historia natural de Los Tuxtlas. Universidad Nacional Autónoma de México, México D.F., Mexico, pp. 25-31.

Morton, J.F., 1987. Fruits of Warm Climates. Published by Julia F. Morton, 20534 SW 92 Ct., Miami, FL 33189, USA, 505 pp. 
Ng, F.S.P., 1991. Diospyros digyna Jacq. In: Verheij, E.W.M., Coronel, R.E. (Eds.), Plant Resources of South-East Asia 2 Edible Fruits and Nuts. Pudoc, Wageningen, The Netherlands, pp. 152-154.

Oyen, L.P.A., 1991. Pouteria sapota (Jacq.) H.E. Moore \& Stearn. In: Verheij, E.W.M., Coronel, R.E. (Eds.), Plant Resources of South-East Asia 2 - Edible Fruits and Nuts. Pudoc, Wageningen, The Netherlands, pp. 259-262.

Pacheco, L., 1981. Flora de Veracruz 16: Ebenaceae. Instituto Nacional de Investigaciones sobre Recursos Bióticos, Xalapa, Veracruz, Mexico, $21 \mathrm{pp}$.

Pagel, H., Enzmann, J., Mutscher, H., 1982. Pflanzennährstoffe in tropischen Böden - ihre Bestimmung und Bewertung. Deutscher Landwirtschaftsverlag, Berlin, Germany, 272 pp.

Pennington, T.D., 1990. Sapotaceae (Flora Neotropica, Monograph 52). The New York Botanical Garden, Bronx, New York, USA, $770 \mathrm{pp}$.

Pennington, T.D., Styles, B.T., Taylor, D.A.H., 1981. Meliaceae (Flora Neotropica, Monograph 28). The New York Botanical Garden, Bronx, New York, USA, 470 pp.

Prevot, P., Ollagnier, M., 1960. Law of the minimum and balanced mineral nutrition. In: Reuther, W. (Ed.), Plant Analysis and Fertilizer Problems. American Institute of Biological Sciences, Washington D.C., USA, pp. 257-277.

Ramos, J.M., del Amo, S., 1992. Enrichment planting in a tropical secondary forest in Veracruz, Mexico. For. Ecol. Manage. 54, 289-304.

Rich, P.M., 1989. A Manual for Analysis of Hemispherical Canopy Photography. Los Alamos National Laboratory, Los Alamos, New Mexico 87545, USA, 80 pp.

Rich, P.M., 1990. Characterizing plant canopies with hemispherical photographs. Remote Sensing Rev. 5, 13-29.

Richards, P.W., Walsh, R.P.D., Baillie, I.C., Greig-Smith, P., 1996. The Tropical Rain Forest. Cambridge University Press, Cambridge, UK, $575 \mathrm{pp}$.

Ricker, M., Mendelsohn, R.O., Daly, D.C., Ángeles, G., 1999. Enriching the rainforest with native fruit trees: an ecological and economic analysis in Los Tuxtlas (Veracruz, Mexico). Ecol. Econ. 31, 439-448.

Rohlf, F.J., Sokal, R.R., 1995. Statistical Tables. W.H. Freeman and Company, New York, USA, 199 pp.

Schachtschabel, P., Blume, H.-P., Hartge, K.-H., Schwertmann, U., 1982. Lehrbuch der Bodenkunde. Ferdinand Enke Verlag, Stuttgart, Germany, 442 pp.

Schlichting, E., Blume, H.P., Stahr, K., 1995. Bodenkundliches
Praktikum (Pareys Studientexte 81). Blackwell WissenschaftsVerlag, Berlin, Germany, 295 pp.

Sharma, P.N., Bisht, S.S., Gupta, S., 1992. Water relations and photosynthesis in zinc-deficient wheat. Acta Bot. Indica 20, 278-282.

Sokal, R.R., Rohlf, F.J., 1995. Biometry. W.H. Freeman and Company, New York, USA, 887 pp.

Soto, M., Gama, L., 1997. Climas. In: González S., E., Dirzo, R., Vogt, R.C. (Eds.), Historia natural de Los Tuxtlas. Universidad Nacional Autónoma de México, México D.F., Mexico, pp. 7-23.

Spiers, J.M., 1993a. Calcium, magnesium, and sodium uptake in rabbit-eye blueberries. J. Pl. Nutr. 16, 825-833.

Spiers, J.M., 1993b. Nitrogen, calcium, and magnesium fertilization affects growth and leaf elemental content of 'Dormanred' raspberry. J. Pl. Nutr. 16, 2333-2339.

St. Clair, J.B., Adams, W.T., 1991. Effects of seed weight and rate of emergence on early growth of open-pollinated Douglas-fir families. For. Sci. 37, 987-997.

Strasburger, E., Noll, F., Schenck, H., Schimper, A.F.W., 1983. Lehrbuch der Botanik für Hochschulen. In: von Denffer, D., Ziegler, H., Ehrendorfer, F., Bresinsky, A., 32 Ed., Gustav Fischer Verlag, Stuttgart, Germany, $1161 \mathrm{pp}$.

SYSTAT, 1996. SYSTAT 6.0 for Windows: Statistics (manual). SPSS Inc., Chicago, USA, 751 pp.

Timmer, V.R., Teng, Y., 1990. Phosphorus-induced micronutrient disorders in hybrid poplar: II. Responses to zinc and copper in greenhouse culture. Pl. Soil 126, 31-40.

Tomar, R.K., Gangwar, M.S., Dwivedi, B.S., 1994. Phosphorus and zinc interaction in sunflower (Helianthus annuus) in Mollisols of Uttar Pradesh. Ind. J. Agron. 39, 270-273.

USDA (United States Department of Agriculture, Soil Survey Staff), 1992. Keys to Soil Taxonomy — SMSS Technical Monograph 19. Pocahontas Press, Blacksburg, Virginia, USA, 541 pp.

Van Wambeke, A., 1992. Soils of the Tropics - Properties and Appraisal. McGraw-Hill, New York, USA, 343 pp.

Whitmore, T.C., Brown, N.D., Swaine, M.D., Kennedy, D., Goodwin-Bailey, C.I., Gong, W.-K., 1993. Use of hemispherical photographs in forest ecology: measurement of gap size and radiation totals in a Bornean tropical rain forest. J. Trop. Ecol. 9, 131-151.

Wright, S.J., 1991. Seasonal drought and the phenology of understory shrubs in a tropical moist forest. Ecology 72, 1643-1657.

Zipperlen, S.W., Press, M.C., 1996. Photosynthesis in relation to growth and seedling ecology of two dipterocarp rain forest tree species. J. Ecol. 84, 863-876. 